\title{
The Application of Electrocoagulation to Treat Meatball Wastewater with Aluminium Electrode
}

\author{
Soeprijanto Soeprijanto ${ }^{1 *}$, Findi Kusuma Wardani ${ }^{1}$, M.Yosi Kurniawan ${ }^{1}$
}

\begin{abstract}
The meatball factory in Keputih, Surabaya produce meatball liquid waste with a COD value of 11,072 mg/L, so it requires special treatment before being discharged into the environment. This research was conducted to treat that meatball liquid waste by electrocoagulation method using aluminum electrodes. The variables were arranged using completely randomized design at $\mathrm{pH}$ variations of 5.5 and 9 , residence time of $15,30,45$ and 60 minutes, number of plates of 4 and 8 , and current density of $312.5 ; 375 ; 156.25 ; 187.5 \mathrm{~A} / \mathrm{m}^{2}$ in batches then will be analyzed for COD, TDS and Turbidity. This research has obtained results that optimal time for electrocoagulation varies from 15-45 minutes after that current density of 187.5 and $375 \mathrm{~A} / \mathrm{m}^{2}$ are slightly better than 156.25 and $312.5 \mathrm{~A} / \mathrm{m}^{2}$ after that $\mathrm{pH} 8$ had better treatment results than pH 5.5, especially in turbidity then the use of 8 aluminum plates at the same electric current had far better results than 4 plates. So that the best efficiency in this wastewater treatment is obtained by removal of COD value up to $94.78 \%$, Turbidity up to $98.68 \%$ and TDS up to $76.63 \%$ at a current density of $187.5 \mathrm{~A} / \mathrm{m} 2$ and $\mathrm{pH} 8$ for 30 minutes.
\end{abstract}

Keywords - COD, Electrocoagulation, Meatball wastewater, TDS, Turbidity

\section{INTRODUCTION}

$\mathrm{O}$ ne of the industries that produces a lot of liquid waste is the meatball factory, such as the meatball factory in Keputih Surabaya. Waste from the meatball industry has similarities with industrial tapioca waste because it has the characteristics of a cloudy white color, pungent smell and slightly foamy on the surface, it happens because the waste contains organic materials such as carbohydrates, Chemical Oxygen Demand (COD) and Biochemical Oxygen Demand (BOD) so, proper treatment is needed before the wastewater can be disposed into the aquatic environment [1].

Industrial wastewater disposal into the water bodies has an impact on decreasing the quality of river water which can harm the environment, especially people who live around the river. These negative impacts such as disturbing human health, disturbing aesthetics due to odors that arise from waste, reduced agricultural yields, decreased pond yields and reduced use of river water by residents [1].

To overcome this problem, it is necessary to treat liquid waste before it is discharged into the environment so that an innovative, cheap, and effective waste treatment method is needed to reduce waste pollutant parameters. There are several methods that can be used to deal with this problem, one of them is electrocoagulation method [14].

Electrocoagulation is a process involving chemical and physical phenomena using sacrificial electrodes for coagulant formation. Aluminum or iron is the most commonly used materials as an anode of electrocoagulation. It is a conventional alternative coagulation process with coagulant formation by sacrificial of anode by electric current between anodescathodes with simultaneous hydroxyl ion formation and hydrogen gas occurs in the cathode. Hydrogen gas will also helps particles flock to separate from water [18].

\footnotetext{
${ }^{1}$ Department of Industrial Chemical Engginering, Institut Teknolog Sepuluh Nopember, Kampus ITS Sukolilo, Surabaya, 60111, Indonesia. E-mail: soeprijanto@chem-eng.its.ac.id
}

Electrocoagulation is influenced by various electrochemical parameters including potential, residence time and $\mathrm{pH}$. In addition, the type of electrode, arrangement and number of electrodes also need to be studied concerning the electrocoagulation process.

In this study, the authors developed a study on electrocoagulation of meatball wastewater which was made to reduce TDS, COD and Turbidity levels by electrocoagulation method with Aluminum (Al) electrodes that focused on varied variable settings in the configuration of $\mathrm{pH}$, current density, number of plates and retention time. Analysis of the sample after electrocoagulation was carried out after all the sediment from the electrocoagulation sludge had settled, so that only water would be analyzed.

\section{METHOD}

Meatball wastewater used in this experiment was obtained from a meatball factory from Keputih, Surabaya. The characteristic of wastewater used has initial COD value of $11,072 \mathrm{mg} / \mathrm{L}$. This experiment held in $\mathrm{pH}$ condition of 5.5 and 8 variable, $\mathrm{pH} 5.5$ means to initial $\mathrm{pH}$ value of wastewater used and $\mathrm{pH} 8$ means to adjusted wastewater $\mathrm{pH}$ using sodium hydroxide, $\mathrm{pH} 8$ is choosen because majority reasearch of electrocoagulation has held on very acidic to neutral of $\mathrm{pH}$ and very base of $\mathrm{pH}$ so it is more interesting to looking for the influence of slightly base $\mathrm{pH}(\mathrm{pH} 8)$ on electrocoagulation rather than repeating variable that has much researched. other materials used beside the wastewater and sodium hydroxide are water, kalium permanganate, oxalic acid, and sulfuric acid for permanganate analysis.

This experiment was conducted in biotechnology laboratory in batches condition. The experiment of treating meatball liquid waste by electrocoagulation was carried out as measuring TDS, COD, $\mathrm{pH}$ and Turbidity of the initial wastewater, then adjusting the $\mathrm{pH}$ of the wastewater using sodium hydroxide according to the variable, then put 
in the waste as much as $10 \mathrm{~L}$ to the reactor, after that connect the electrocoagulation device to the DC power supply and adjust its electric current to desired variable, after that wait the process running for a certain period according to the variable, after the electrocoagulation process has finished, opens the valve output of waste products and move the wastewater products to a beaker glass until all sediment settled, then sample is taken from clear zone of wastewater at the top with a volume pipette and analyze the sample by measuring TDS, COD, $\mathrm{pH}$ and Turbidity. The electrocoagulation consists of two components, that is an electrocoagulation bath and electrode plate (Figure 1)
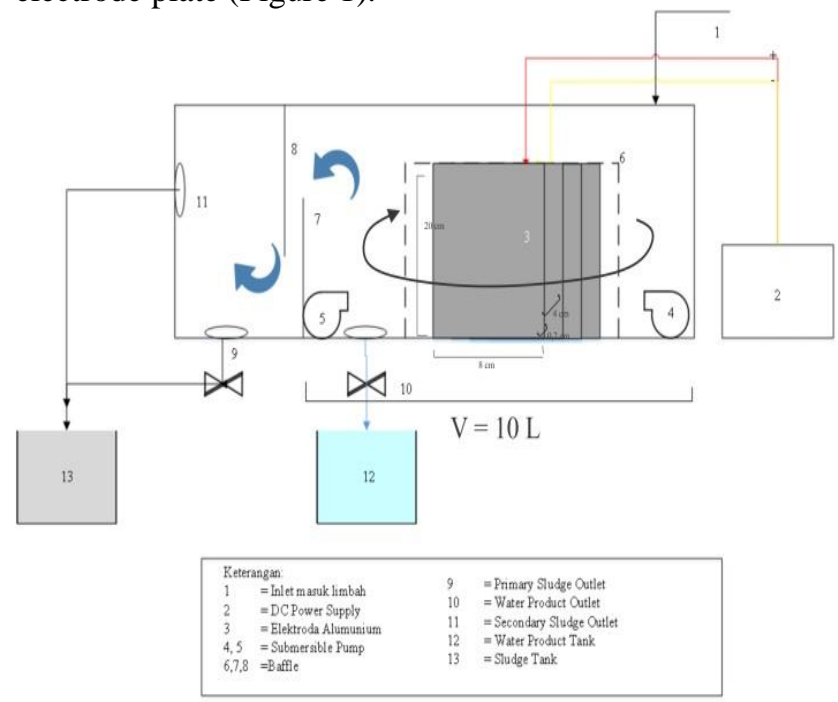

Figure 1. Schematic Diagram of Electrocoagulation

The electrocoagulation bath was made with a length of $20 \mathrm{~cm}$, a width of $20 \mathrm{~cm}$ and a height of $30 \mathrm{~cm}$. This tub is made of glass with a thickness of $0.5 \mathrm{~cm}$. The electrodes consist of 4 cathodes and 8 cathodes made of aluminum, with each of them are measured as $8 \mathrm{~cm}$ wide, $20 \mathrm{~cm}$ long and $0.2 \mathrm{~cm}$ thick. The cathode is powered by direct current and arranged in monopolar and parallel. It is also provided two submersible pumps in the bath to properly circulate the wastewater.

The waste used in this experiment is the original wastewater came from cooking process of meatball industries in Keputih, Surabaya. Parameters tested were organic materials in the form of Chemical Oxygen Demand (COD), turbidity, and TDS. COD examination is using permanganometry method refers to SNI 06-45711998. Meanwhile, the Turbidity parameter analysis uses a turbiditimeter with reference to SNI 6989.20:2009 and for TDS testing is refers to SNI 6989.27:2019 using TDS meter.

In this study, the current density variation was 312.5 $\mathrm{A} / \mathrm{m}^{2} ; 375 \mathrm{~A} / \mathrm{m}^{2} ; 156.25 \mathrm{~A} / \mathrm{m}^{2} ; 187.5 \mathrm{~A} / \mathrm{m}^{2}$; variations in the number of electrode plates was 4 and 8 , variation of $\mathrm{pH}$ was 5.5 and 8 and variations in contact time was 15 minutes, 30 minutes, 45 minutes, and 60 minutes.

\section{RESULTS AND DISCUSSION}

3.1 Effect of Current Density, pH, Retention Time and Number of Electrodes on COD Removal

Chemical oxygen demand (COD) is the amount of oxygen needed to decompose all organic matter in the water by oxidization through chemical reactions. This parameter is also very important in determining the quality for the liquid waste before discharged into the environment, because COD value describes the total amount of organic matter present in the water. So, the following is graphs of the effect of electrocoagulation variables on the COD value of meatball liquid waste.

Figure 2 shows the results of the COD value for the $\mathrm{pH}$ 5.5 and 8 using current density variables of $312.5 \mathrm{~A} / \mathrm{m}^{2}$ using $4 \mathrm{Al}$ electrodes. The results showed that the COD removal had a better decrease from 7,704 to $764 \mathrm{mg} / \mathrm{L}$ at the initial $\mathrm{pH}$ of 5.5 for 45 minutes with $90 \%$ removal compared with COD removal from 6,482 to $1,303 \mathrm{mg} / \mathrm{L}$ at a $\mathrm{pH}$ of 8 for 45 minutes with percent removal only of $80 \%$.

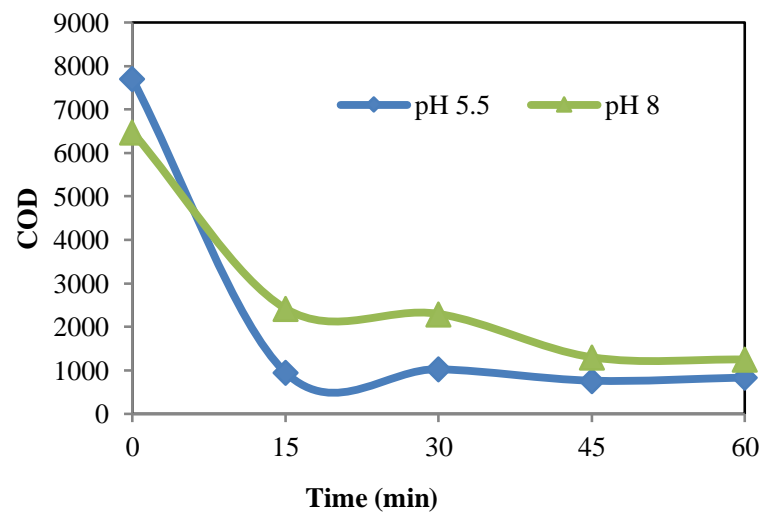

Figure 2. The effect of the initial $\mathrm{pH}$ of 5.5 and 8 on the COD value at a current density of $312.5 \mathrm{~A} / \mathrm{m}^{2}$

The Figure 3 indicates the results of the COD removal at the $\mathrm{pH} 5.5$ and 8 using current density of $375 \mathrm{~A} / \mathrm{m}^{2}$ with 4 $\mathrm{Al}$ electrodes. The results showed COD removal decreased from $11,440 \mathrm{mg} / \mathrm{L}$ to $2,174 \mathrm{mg} / \mathrm{L}$ at a $\mathrm{pH}$ of 5.5 for $30 \mathrm{~min}$ with removal efficiency of $81 \%$ and at $\mathrm{pH}$ of $8 \mathrm{COD}$ removal decreased from 9,037 to $1931 \mathrm{mg} / \mathrm{L}$ for 30 minutes with $81 \%$ removal.

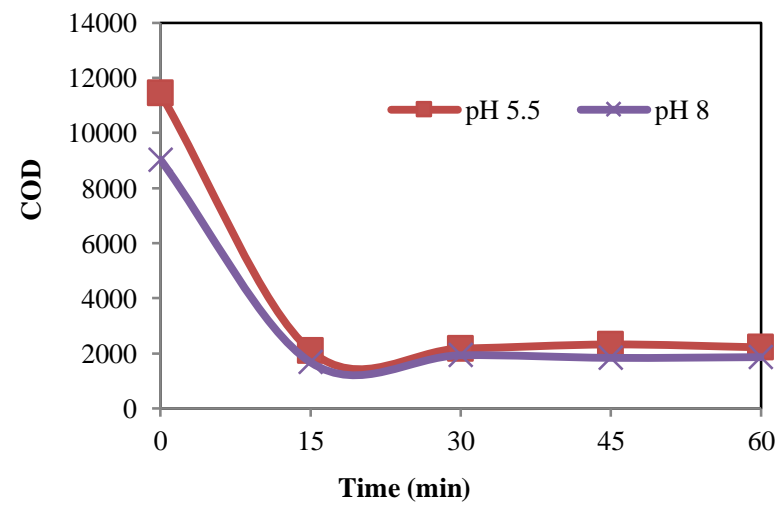

Figure 3. The effect of the initial $\mathrm{pH}$ of 5.5 and 8 on the COD value at a current density of $375 \mathrm{~A} / \mathrm{m}^{2}$

The Figure 4 indicates the results of the COD removal at the $\mathrm{pH} 5.5$ and 8 using current density of $156.25 \mathrm{~A} / \mathrm{m}^{2}$ with 8 Al electrodes. The results showed COD removal decreased from $4,008 \mathrm{mg} / \mathrm{L}$ to $410 \mathrm{mg} / \mathrm{L}$ at a $\mathrm{pH}$ of 5.5 for 45 min with removal efficiency of $90 \%$ and at $\mathrm{pH}$ of 8 COD removal decreased from 6,831 to $329 \mathrm{mg} / \mathrm{L}$ for 45 minutes with $95 \%$ removal. 


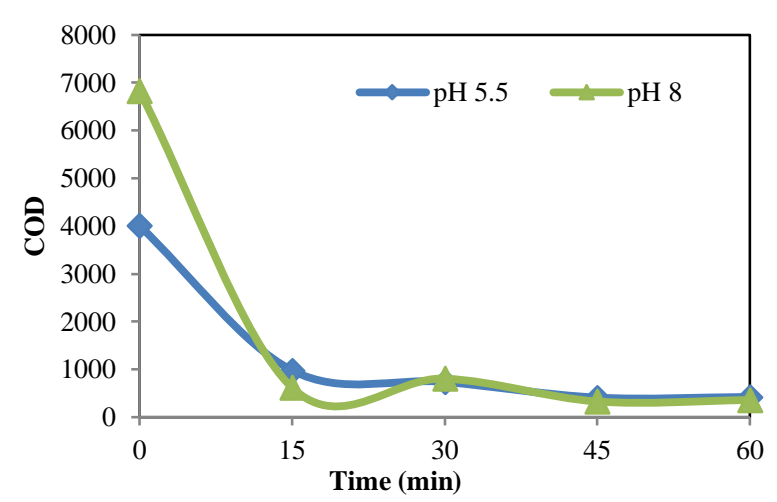

Figure 4. The effect of the initial $\mathrm{pH}$ of 5.5 and 8 on the COD value at a current density of $156.25 \mathrm{~A} / \mathrm{m}^{2}$

The Figure 5 indicates the results of the COD removal at the $\mathrm{pH} 5.5$ and 8 using current density of $187.5 \mathrm{~A} / \mathrm{m}^{2}$ with $8 \mathrm{Al}$ electrodes. The results showed COD removal decreased from 5,582 to $343 \mathrm{mg} / \mathrm{L}$ at a $\mathrm{pH}$ of 5.5 for 30 min with removal efficiency of $94 \%$ and at $\mathrm{pH}$ of $8 \mathrm{COD}$ removal decreased from 4,982 to $360 \mathrm{mg} / \mathrm{L}$ for 30 minutes with $93 \%$ removal.

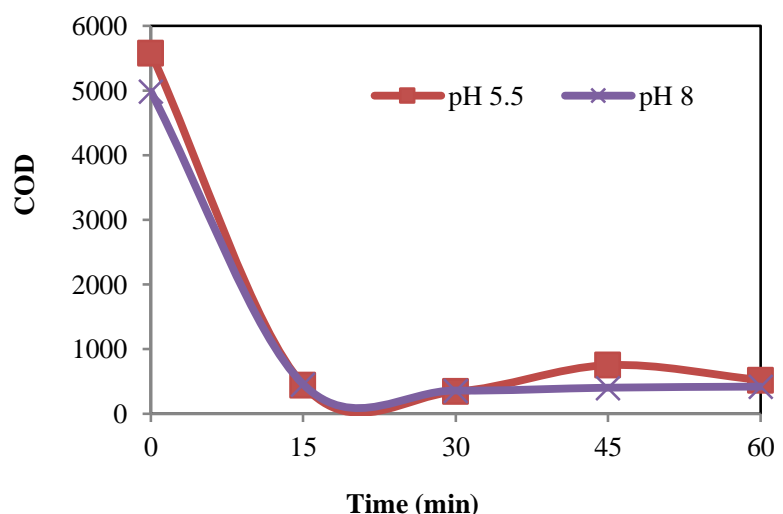

Figure 5. The effect of the initial $\mathrm{pH}$ of 5.5 and 8 on the COD value at a current density of $187,5 \mathrm{~A} / \mathrm{m}^{2}$

So, based on the four graphs above, the optimal time for $\%$ COD removal is 30 minutes with $94 \%$ removal at a current density of $187.5 \mathrm{~A} / \mathrm{m}^{2}$ with $\mathrm{pH}$ of 8 by using 8 electrodes.

The four parameters above indicates that the electrocoagulation process will provide optimum results for the removal efficiency of treating meatball wastewater under operating conditions with high current density (187.5 $\left.\mathrm{A} / \mathrm{m}^{2}\right)$, numerous electrode pairs (8 electrode plates) and proper residence time in the reactor $(30$ minutes).

Optimal electrocoagulation result occurs at 30 minutes when compared to variables of 15,45 and 60 minutes. This is in accordance with the literature which states that the longer electrocoagulation process occur, the more formation of $\mathrm{H}_{2}$ gas and $\mathrm{OH}^{-}$happens so more coagulant complexes will able to bind the pollutants as the amount of hydrogen gas [2]. But the occurrence of a slight increase in results in a variable time of 45 minutes for the current density of $187.5 \mathrm{~A} / \mathrm{m}^{2}$ and $\mathrm{pH} 5.5$ may be due to the poor sampling or COD analysis.

The initial $\mathrm{pH}$ of waste to be processed on electrocoagulation is a bit more optimal in $\mathrm{pH} 8$ when compared to $\mathrm{pH} 5.5$ this is in accordance with the literature states that the optimal $\mathrm{pH}$ for electrocoagulation is at $\mathrm{pH}$
$6-9$, increased $\mathrm{pH}$ of the water is in line with the length of time of electrocoagulatio, which results in a decrease in pollutant levels in waste due to the electrocoagulation, there is accumulation of an increase in hydroxide ions resulting in lower energy formation of $\mathrm{H}_{2}$ and $\mathrm{O}_{2}$ gases so the flotation performance are generated [6].

Electrocoagulation results shows slightly faster optimal results in the current density of $187.5 \mathrm{~A} / \mathrm{m}^{2}$ compared to the current density of $156.25 \mathrm{~A} / \mathrm{m}^{2}$ as well as in the current density of $375 \mathrm{~A} / \mathrm{m}^{2}$ shows slightly faster optimal results when compared to the current density of $312.5 \mathrm{~A} / \mathrm{m}^{2}$, This is in accordance with the literature which states that the greater electric current is given, the hidrogen bubble density is increased but the size will decreased, so it will accelerate the decrease of pollutant and increase sludge flotation [7]. Theoretically, according to Ohm's law, the voltage is directly proportional to electric currents. The higher voltage given then the current will also get higher. Faraday's law mentions that the higher the current, the higher the rate of release of metal cations, so the efficiency of the pollutant's removal in the sample becomes higher [8].

For the number of $\mathrm{Al}$ electrode plate, the optimal results is obtained on the use of 8 electrodes when compared to 4 electrodes. It is suitable in accordance with the literature that explains that more electrodes in the same process conditions, the more $\mathrm{Al}^{3+}$ is released from the oxidation reaction on the aluminum electrode which serves as an anode and it will remove and floats more pollutants in the tank. The increase of the formation of $\mathrm{Al}^{3+}$ was followed by an increase in the formation of $\mathrm{Al}(\mathrm{OH})_{3}$ which is functions as a coagulant but an increase in the number of aluminum electrode pairs in the same voltage and electric current, has an optimum limit which means that the more number of aluminum electrode pairs used does not always mean to greater decreased of liquid waste levels [9].

From the data obtained, it can be said that the electrocoagulation wastewater treatment method was successful in reducing the COD value but it did not able to meet the quality standard limits. Which is in the quality standard explain that maximum COD value for domestic water is $300 \mathrm{mg} / \mathrm{L} \mathrm{[15],} \mathrm{however} \mathrm{in} \mathrm{this} \mathrm{research,} \mathrm{the}$ maximum COD removal of meatball liquid waste after electrocoagulation is still above the waste quality standard that is $360 \mathrm{mg} / \mathrm{L}$.

\subsection{Effect of electrocoagulation on Turbidity}

Turbidity describes the optical properties which is determined based on the amount of light absorbed and emitted by the materials in the water. The higher value of dissolved solids is not always followed by high turbidity. Turbidity or water turbidity is caused by biological contaminants, macromolecular compounds, insoluble inorganic compounds and suspended or colloidal particles [10] Although the turbidity parameter has not been included in the quality standard of water, the level of turbidity is one of the important parameters for waste before being discharged into the environment because the level of turbidity in the waters can affect the ecosystem. The following is graphs of the effect of electrocoagulation on the turbidity value of meatball liquid waste.

Figure 6 explains the turbidity value results for $\mathrm{pH}$ of 5.5 and 8 by using current density variables of $312.5 \mathrm{~A} / \mathrm{m}^{2}$ using $4 \mathrm{Al}$ electrodes. The turbidity value of the initial 
liquid meatball waste with a $\mathrm{pH}$ of 5.5 had a maximum decrease from 2,860 NTU to 279 NTU at a contact time of 45 minutes with $90 \%$ removal then the turbidity value of the initial liquid meatball waste with a $\mathrm{pH}$ of 8 showed a maximum decrease from 3,190 NTU to 53 NTU at a contact time of 45 minutes with $98 \%$ removal.

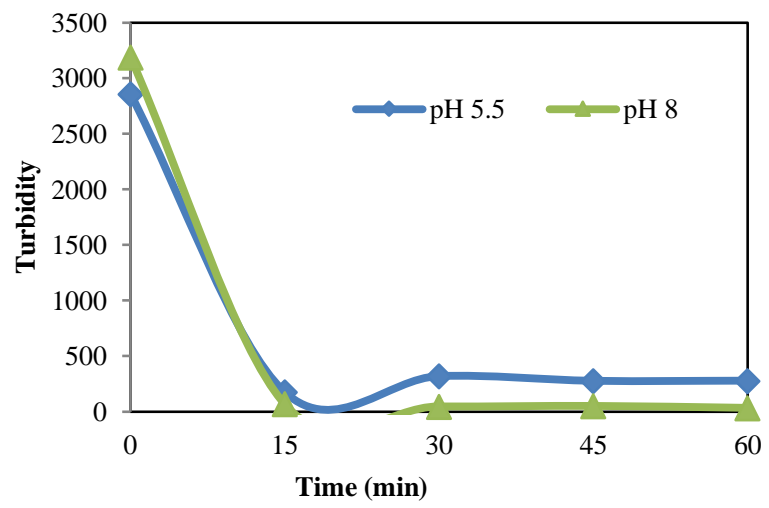

Figure 6. The effect of the initial $\mathrm{pH}$ of 5.5 and 8 on the turbidity value at a current density of $312.5 \mathrm{~A} / \mathrm{m}^{2}$

Figure 7 explains the turbidity value results for $\mathrm{pH}$ of 5.5 and 8 by using current density variables of $375 \mathrm{~A} / \mathrm{m}^{2}$ using $4 \mathrm{Al}$ electrodes. The turbidity value of the initial liquid meatball waste with a $\mathrm{pH}$ of 5.5 had a maximum decrease from 2,860 NTU to $231 \mathrm{NTU}$ at a contact time of 45 minutes with $92 \%$ removal then the turbidity value of the initial liquid meatball waste with a $\mathrm{pH}$ of 8 showed a maximum decrease from 3,190 NTU to $55 \mathrm{NTU}$ at a contact time of 45 minutes with $98 \%$ removal.

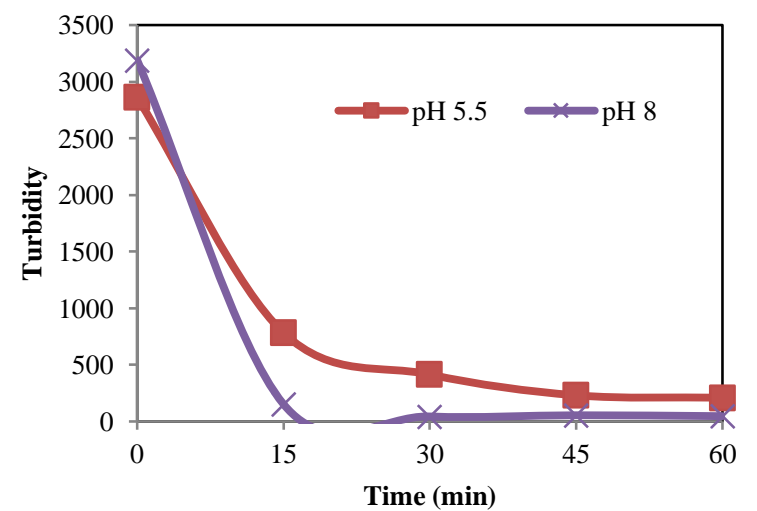

Figure 7. The effect of the initial $\mathrm{pH}$ of 5.5 and 8 on the turbidity value at a current density of $375 \mathrm{~A} / \mathrm{m}^{2}$

Figure 8 explains the turbidity value results for $\mathrm{pH}$ of 5.5 and 8 by using current density variables of $156.25 \mathrm{~A} / \mathrm{m}^{2}$ using $8 \mathrm{Al}$ electrodes. The turbidity value of the initial liquid meatball waste with a $\mathrm{pH}$ of 5.5 had a maximum decrease from 1,482 NTU to 207 NTU at a contact time of 30 minutes with $86 \%$ removal then the turbidity value of the initial liquid meatball waste with a $\mathrm{pH}$ of 8 showed a maximum decrease from 1312 NTU to 19 NTU at a contact time of 45 minutes with $99 \%$ removal.

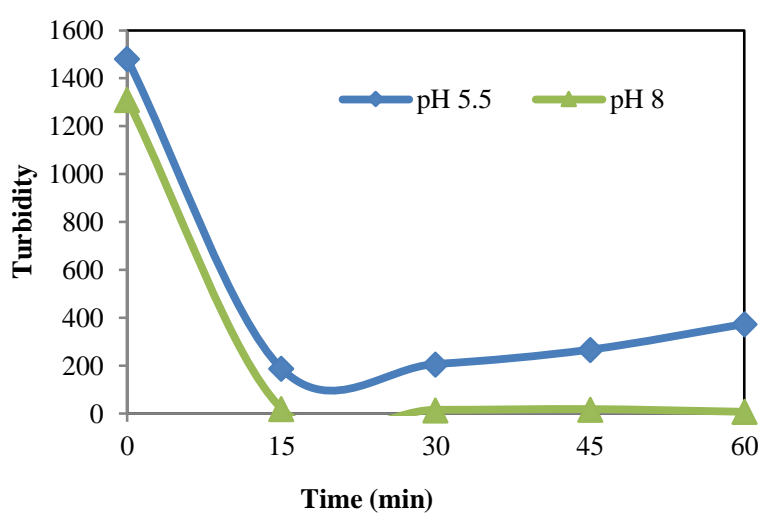

Figure 8. The effect of the initial $\mathrm{pH}$ of 5.5 and 8 on the turbidity value with 8 electrodes at a current density of $156.25 \mathrm{~A} / \mathrm{m}^{2}$

Figure 9 explains the turbidity value results for $\mathrm{pH}$ of 5.5 and 8 by using current density variables of $187.5 \mathrm{~A} / \mathrm{m}^{2}$ using $8 \mathrm{Al}$ electrodes. The turbidity value of the initial liquid meatball waste with a $\mathrm{pH}$ of 5.5 had a maximum decrease from 1444 NTU to 4 NTU at a contact time of 30 minutes with $99 \%$ removal then the turbidity value of the initial liquid meatball waste with a $\mathrm{pH}$ of 8 showed a maximum decrease from 1,710 NTU to $5 \mathrm{NTU}$ at a contact time of 45 minutes with $99 \%$ removal.

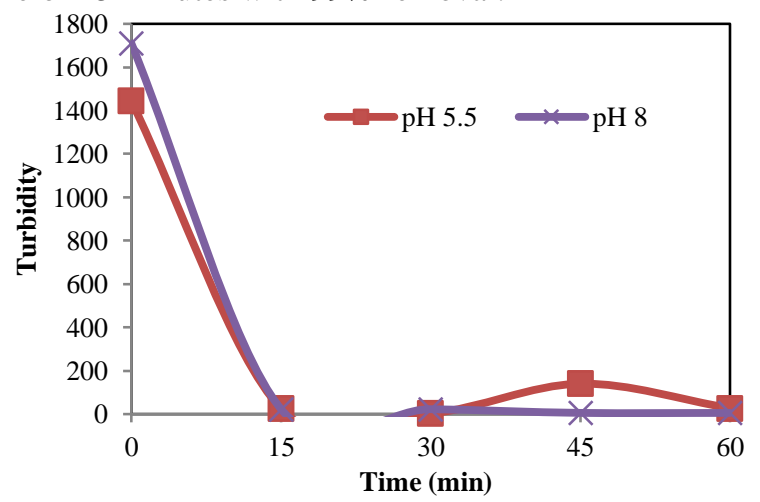

Figure 9. The effect of the initial $\mathrm{pH}$ of 5.5 and 8 on the turbidity value at a current density of $187.5 \mathrm{~A} / \mathrm{m}^{2}$

So, based on the four graphs above, the optimal time for $\%$ Turbidity removal is 30 minutes with $99 \%$ removal at a current density of $187.5 \mathrm{~A} / \mathrm{m}^{2}$ with $\mathrm{pH}$ of 8 by using 8 electrodes.

The four parameters above indicates that the electrocoagulation process will provide optimum result on reducing the turbidity of meatball liquid waste under operating conditions with higher current density (187.5 $\mathrm{A} / \mathrm{m}^{2}$ ), numerous electrode pairs (8 electrode plates) and proper residence time in the reactor (45 minutes).

From the graph, it can be seen that the final turbidity of wastewater after being processed by electrocoagulation with 4 electrodes and 8 pairs of electrodes has given different results. The final turbidity waste processed with 4 electrodes is lower than 8 electrodes, this is due to the effectiveness of electrocoagulation is influenced by the number of electrodes used, the more electrodes used so the lower turbidity of waste can be achieved because the more electrodes used, the more $\mathrm{AL}^{3+}$ ions are decomposed, so the opportunity to react with $\mathrm{OH}^{-}$to form $\mathrm{Al}(\mathrm{OH})_{3}$ to coagulate suspended solids is getting higher [3].

The $\mathrm{pH}$ value around the cathode is getting higher during the electrolysis process, the formation of $\mathrm{OH}$ caused the 
increase in $\mathrm{pH}$ in the cathode ${ }^{-}$, the higher the $\mathrm{pH}$ around the cathode, the greater the reduction of the turbidity [11]. Based on the graph, better turbidity value occurs at $\mathrm{pH} 8$ when compared to $\mathrm{pH}$ 5.5.

Electrocoagulation results shows slightly faster optimal results in the current density of $187.5 \mathrm{~A} / \mathrm{m}^{2}$ compared to the current density of $156.25 \mathrm{~A} / \mathrm{m}^{2}$ as well as in the current density of $375 \mathrm{~A} / \mathrm{m}^{2}$ shows slightly faster optimal results when compared to the current density of $312.5 \mathrm{~A} / \mathrm{m}^{2}$, This is in accordance with the literature which states that greater electric current given, the hidrogen bubble density is increased but the size will decrease, so it will accelerate the decrease of the pollutant and increase sludge flotation [7].

Then the longer residence time of waste in the electrocoagulation reactor, the impurities causes of water turbidity will be coagulated by the anode then it will be lifted by hydrogen gas formed on the surface of the cathode so it binds the particles of dissolved and suspended solids with the formation of black brown foam that made the turbidity of waste water is getting lower [12]. But too long residence time can made the amount of flock led to too much and ends to the saturation on the electrode plate and it will reduce the ability of electrodes to attract ions in water [13]. In addition, when the electrocoagulation runs too long, the amount of dissolved aluminum in water will increase, resulting in increased pollution value again [2]. Therefore, for the value of the turbidity obtained for optimal results has occurred at 45 minutes

\subsection{Effect of electrocoagulation on TDS}

Total dissolved solids are dissolved materials (diameter $<10^{-6} \mathrm{~mm}$ ) and colloids (diameter $10^{-6}-10^{-3} \mathrm{~mm}$ ) in the form of chemical compounds and other materials, which are not filtered on filter paper with a diameter of 0.45 [4]. Referring to Government Regulation No. 82 of 2001 concerning Water Quality Treatment and Water Pollution Control, it explains that the maximum TDS value to be used as type 2 water is $1000 \mathrm{mg} / \mathrm{L}$. The following is the graph of the effect of electrocoagulation on the TDS value of meatball liquid waste.

Figure 10 explains the TDS value results for the $\mathrm{pH}$ of 5.5 and 8 by using current density variables of $312.5 \mathrm{~A} / \mathrm{m}^{2}$ using $4 \mathrm{Al}$ electrodes. The TDS value of initial liquid meatball waste with a $\mathrm{pH}$ of 5.5 had a maximum decrease from $7,517 \mathrm{mg} / \mathrm{L}$ to $2,646 \mathrm{mg} / \mathrm{L}$ at a contact time of 45 minutes with removal efficiency of $65 \%$ then the TDS value of the initial liquid meatball waste with a $\mathrm{pH}$ of 8 showed a maximum decrease from $7,097 \mathrm{mg} / \mathrm{L}$ to 2,302 $\mathrm{mg} / \mathrm{L}$ at a contact time of 30 minutes with $68 \%$ removal.

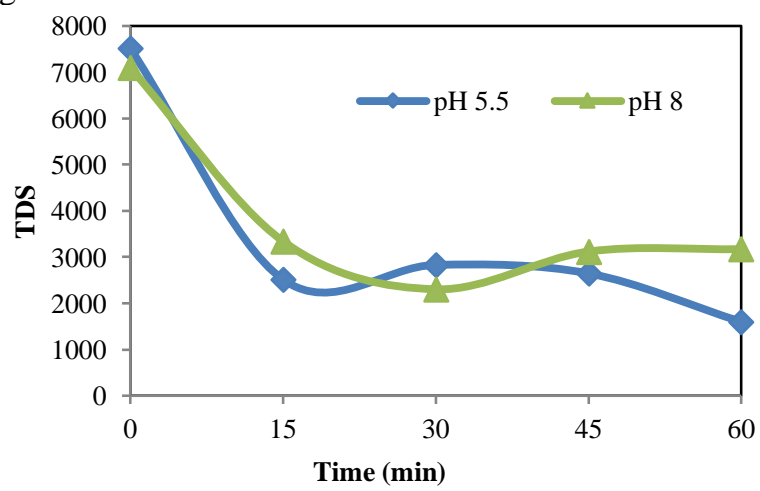

Figure 10. The effect of the initial $\mathrm{pH}$ of 5.5 and 8 on the TDS value at a current density of $312,5 \mathrm{~A} / \mathrm{m}^{2}$
Figure 11 explains the TDS value results for the $\mathrm{pH}$ of 5.5 and 8 by using current density variables of $375 \mathrm{~A} / \mathrm{m}^{2}$ using $4 \mathrm{Al}$ electrodes. The TDS value of initial liquid meatball waste with a $\mathrm{pH}$ of 5.5 had a maximum decrease from $7,647 \mathrm{mg} / \mathrm{L}$ to $2,142 \mathrm{mg} / \mathrm{L}$ at a contact time of 15 minutes with removal efficiency of $72 \%$ then the TDS value of the initial liquid meatball waste with a $\mathrm{pH}$ of 8 showed a maximum decrease from $7,707 \mathrm{mg} / \mathrm{L}$ to 1,415 $\mathrm{mg} / \mathrm{L}$ at a contact time of 30 minutes with $82 \%$ removal.

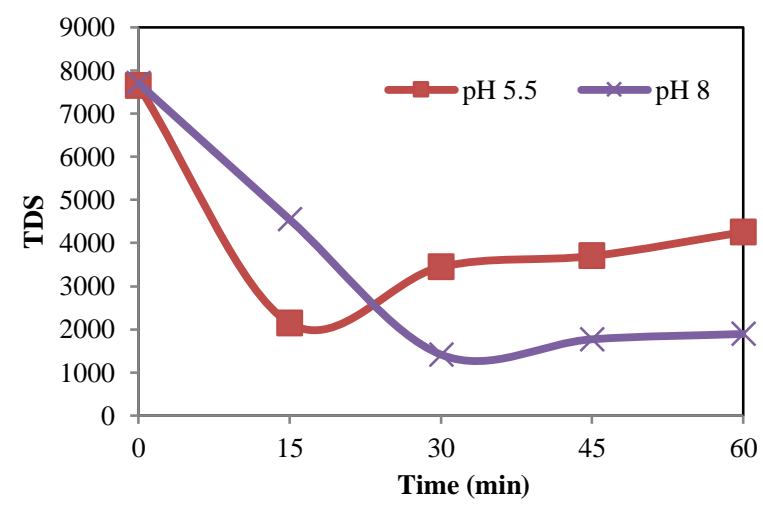

Figure 11. The effect of the initial $\mathrm{pH}$ of 5.5 and 8 on the TDS value at a current density of $375 \mathrm{~A} / \mathrm{m}^{2}$

Figure 12 explains the TDS value results for the $\mathrm{pH}$ of 5.5 and 8 by using current density variables of 156.25 $\mathrm{A} / \mathrm{m}^{2}$ using $8 \mathrm{Al}$ electrodes. The TDS value of initial liquid meatball waste with a $\mathrm{pH}$ of 5.5 had a maximum decrease from $6,267 \mathrm{mg} / \mathrm{L}$ to $584 \mathrm{mg} / \mathrm{L}$ at a contact time of 30 minutes with removal efficiency of $91 \%$ then the TDS value of the initial liquid meatball waste with a $\mathrm{pH}$ of 8 showed a maximum decrease from $7,097 \mathrm{mg} / \mathrm{L}$ to 971 $\mathrm{mg} / \mathrm{L}$ at a contact time of 30 minutes with $86 \%$ removal.

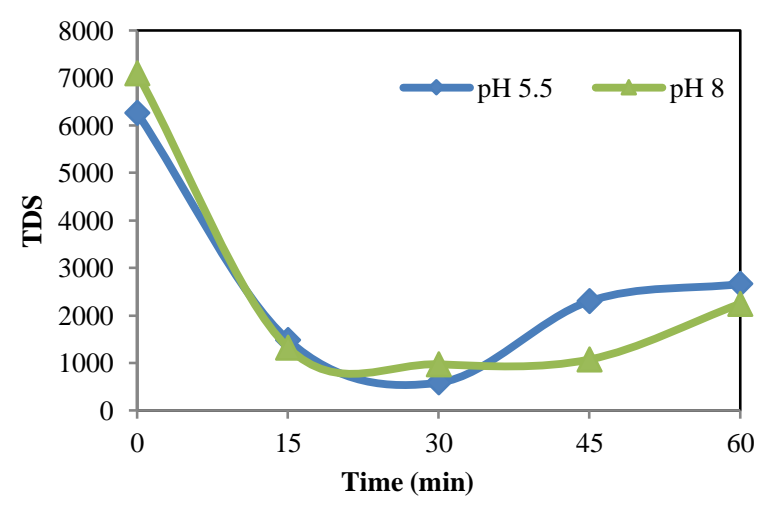

Figure 12. The effect of the initial $\mathrm{pH}$ of 5.5 and 8 on the TDS value at a current density of $156.25 \mathrm{~A} / \mathrm{m}^{2}$

Figure 13 explain the results of TDS value for the $\mathrm{pH}$ of 5.5 and 8 by using current density variables of $187.5 \mathrm{~A} / \mathrm{m}^{2}$ using $8 \mathrm{Al}$ electrodes. The TDS value of initial liquid meatball waste with a $\mathrm{pH}$ of 5.5 had a maximum decrease from $6,667 \mathrm{mg} / \mathrm{L}$ to $302.8 \mathrm{mg} / \mathrm{L}$ at a contact time of 15 minutes with removal efficiency of $95 \%$ then the TDS value of the initial liquid meatball waste with a $\mathrm{pH}$ of 8 showed a maximum decrease from $6,527 \mathrm{mg} / \mathrm{L}$ to 1,442 $\mathrm{mg} / \mathrm{L}$ at a contact time of 45 minutes with $78 \%$ removal. 


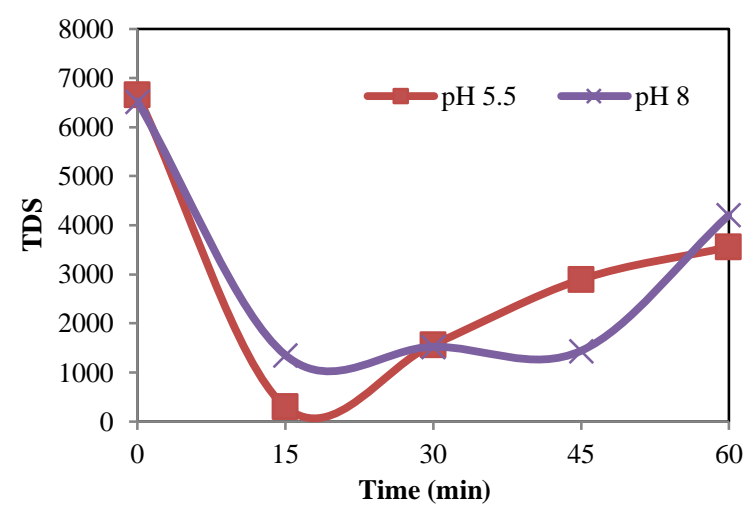

Figure 13. The effect of the initial $\mathrm{pH}$ of 5.5 and 8 on the TDS value at a current density of $187.5 \mathrm{~A} / \mathrm{m}^{2}$

The four parameters above indicates that the electrocoagulation process will provide optimum results for the efficiency of reducing TDS of meatball liquid waste under operating conditions with high current density $\left(187.5 \mathrm{~A} / \mathrm{m}^{2}\right), \mathrm{pH} 8$, large number of electrode pairs $(8$ electrode plates) and a proper retention time (15 minutes).

From the graph it can be seen that using 8 electrode plates gives better result when compared to 4 electrodes. The more electrodes used, TDS removal are becoming higher, it because one of the factors that influences the electrocoagulation process is the number of electrodes used. The more electrodes used, the electrocoagulation process is getting better than the result of TDS removal is also getting higher [5].

The $\mathrm{pH}$ value around the cathode is getting higher during the electrolysis process, the increase in $\mathrm{pH}$ of the cathode was caused by the formation of $\mathrm{OH}-$, the higher of $\mathrm{pH}$ around the cathode, the greater reduction of TDS [11]. On the graph, it has not observed such a big difference on TDS result between $\mathrm{pH} 5,5$ and 8 but $\mathrm{pH} 8$ looks like it has given a more stable lower TDS removal result than $\mathrm{pH} 5,5$.

From the graphics, it can be observed that electrocoagulation results shows slightly faster optimal results in the current density of $187.5 \mathrm{~A} / \mathrm{m}^{2}$ compared to the current density of $156.25 \mathrm{~A} / \mathrm{m}^{2}$ as well as in the current density of $375 \mathrm{~A} / \mathrm{m}^{2}$ shows slightly faster optimal results when compared to the current density of $312.5 \mathrm{~A} / \mathrm{m}^{2}$, This is in accordance with the literature which states that the greater electric current given, the hidrogen bubble density is increased but the size will be decreased, so it will accelerate the decrease of the pollutant and increase sludge flotation [7].

Then the longer residence time of the waste in the electrocoagulation reactor, the more impurities causes of water turbidity will be coagulated by the anode then will be lifted by hydrogen gas formed on the surface of the cathode so that, it binds the particles of dissolved and suspended solids with the formation of black brown foam that made the turbidity of waste water is getting smaller [12]. Other literature also mentioned in his research that, the contact time between water and electrodes affected its removal efficiency but the ability of electrodes in reducing water pollutant is limited, even though the contact time is extended, the electrode removal ability will be reduced because the electrode has experienced saturation [17]. One of the causes of the decreased removal is reduced formation of $\mathrm{OH}$ - in the cathode due to the accumulation of the attached sediment, in the other way, when the electrocoagulation runs too long, the aluminum will be more dissolved in waste, increasing pollution value again [2], it may make a re increase in TDS parameters in electrocoagulation. Therefore, for TDS values obtained for optimal results occur at 15 minutes.

From the data obtained, retention time of the wastewater in the electrocoagulation reactor at 15 minutes with current density of $187,5 \mathrm{~A} / \mathrm{m} 2$, and $\mathrm{pH} 8$ has met its optimum parameter because it was successful in reducing the TDS value by $95 \%$ to $302.8 \mathrm{mg} / \mathrm{L}$ and able to met the maximum TDS quality standards value of $1000 \mathrm{mg} / \mathrm{L}$ [16].

\section{CONCLUSION}

The optimal variable for treatment of meatball wastewater by electrocoagulation are at the number of 8 plates, because it gives much better results than 4 plates then the current density of $375 \mathrm{~A} / \mathrm{m}^{2}$ and $187.5 \mathrm{~A} / \mathrm{m}^{2}$ in this study is better than current density of $312.5 \mathrm{~A} / \mathrm{m}^{2}$ and $156.25 \mathrm{~A} / \mathrm{m}^{2}$ but it is not significant after that, the general optimum time varies at 30-45 minutes of electrocoagulation even though few variables has shown 15 minutes had found its optimum result then $\mathrm{pH} 8$ of initial wastewater conditions had obtained better results than initial $\mathrm{pH}$ of 5.5 especially at turbidity parameter.

In all parameters has analyzed after electrocoagulation of the meatball wastewater, only TDS that have achieved its limit of $1000 \mathrm{mg} / \mathrm{L}$ which is in this study it has TDS value results of $302.8 \mathrm{mg} / \mathrm{L}(95 \%)$, then electrocoagulation work so well in turbidity value, because it can reduce turbidity as much to 5 NTU (99\%) but in COD parameter electrocoagulation has not been able to meet the waste quality standards of $300 \mathrm{mg} / \mathrm{L}$ because its only able to reduce waste pollutants up to $360 \mathrm{mg} / \mathrm{L}(90 \%)$.

\section{ACKNOWLEDGEMENTS}

Authors are thanked to the meatball factory in Keputih, Surabaya for their support on providing the material for research. Authors also grateful to our lectures at Department of Industrial Chemical Enginering, Institut Teknologi Sepuluh Nopember and reviewers for their advice and suggestions to the manuscript.

\section{REFERENCES}

[1] M. N. Abduh, Ilmu dan Rekayasa Lingkungan, vol. 1. Makasar: Sah Media, 2018.

[2] R. Budiany, S. P. Yayok, and M. Mohamad, "Proses elektrokoagulasi pengolahan limbah laundry," Envirotek J. Ilm. Tek. Lingkung., vol. 6, no. 1, pp. 15-22, 2014.

[3] P. Holt, G. Barton, and C. Mitchell, "Electrocoagulation as a wastewater treatment," Third Annu. Aust. Environ. Eng. Res. Event, vol. 1000, pp. 41-46, 1999.

[4] H. Effendi, "Telaah kualitas air bagi pengelolaan sumberdaya dan lingkungan perairan," 2003.

[5] K. N. Hafni, "Pengolahan Air Buangan Pencelupan Tekstil dengan Proses Elektrokoagulasi Memakai Elektroda Aluminium," 2007.

[6] A. M. H. Elnenay, E. Nassef, G. F. Malash, and M. H. A. Magid, "Treatment of drilling fluids wastewater by electrocoagulation," Egypt. J. Pet., vol. 26, no. 1, pp. 203-208, 2017.

[7] E. Bazrafshan, K. A. Ownagh, and A. H. Mahvi, "Application of electrocoagulation process using iron and aluminum electrodes for fluoride removal from aqueous environment," $E$ Journal Chem., vol. 9, no. 4, pp. 2297-2308, 2012.

[8] Satriananda, "Penyisihan Besi (Fe) Dalam Air Dengan Proses Elektrokoagulasi,” J. Reaksi (Journal Sci. Technol., vol. 9, no. 2, pp. 1-6, 2011

[9] S. Sutanto, "PERBANDINGAN EFISIENSI BAK PROSES 
DUA SEL DAN TIGA SEL DALAM MENURUNKAN KANDUNGAN BESI (Fe) DALAM AIR LIMBAH SECARA ELEKTROKOAGULASI DENGAN KATODA DARI KARBON BEKAS BATERAI," J. Poli-Teknologi, vol. 10, no. $1,2011$.

[10] M. F. Ním, F. Othman, J. Sohaili, and Z. Fauzia, "Removal of COD and turbidity to improve wastewater quality using electrocoagulation technique," MJAS, vol. 11, pp. 198-205, 2007.

[11] H. K. Abdel-Aal and I. A. Hussein, "Parametric study for saline water electrolysis: part III-precipitate formation and recovery of magnesium salts," Int. J. Hydrogen Energy, vol. 18, no. 7, pp. 553-556, 1993.

[12] A. Rahman and H. Purwoto, "Penggunaan Metode Elektrokoagulasi Sebagai Alternatif Pengolahan Air Bersih Tanpa Bahan Kimia," AGROTEKNOSE (Jurnal Teknol. dan Enj. Pertanian), vol. 7, no. 2, 2018.

[13] L. Kaslum et al., "PENGOLAHAN AIR PAYAU MENJADI AIR BERSIH MENGGUNAKAN METODE ELEKTROKOAGULASI," KINETIKA, vol. 12, no. 1, pp. 1-8, 2021.

[14] R. Susetyaningsih and P. Endro Kismolo, "Kajian proses elektrokoagulasi untuk pengolahan limbah cair," 2008.

[15] Kementerian Lingkungan Hidup, "Peraturan menteri lingkungan hidup republik indonesia nomor 5 tahun 2014 tentang baku mutu air limbah," Jakarta Kementeri. Lingkung. Hidup Republik Indones., 2014.

[16] Peraturan Pemerintah No 82 Tahun 2001 Tentang Pengelolaan Kualitas Air dan Pengendalian Pencemaran Air. 2001.

[17] L. K. Dewi, R. A. Azfah, and E. S. Soedjono, "Rancang bangun alat pemurni air payau sederhana dengan membran reverse osmosis untuk memenuhi kebutuhan air minum masyarakat miskin daerah pesisir," J. Tek. Lingkungan, Fak. Tek. Sipil dan Perencanaan, ITS Surabaya, 2014.

[18] S. Soeprijanto, L. Pudjiastuti, and R. O. S. Gurning, "Penyisihan Minyak dalam Emulsi Air Bilga Menggunakan Proses Elektrokoagulasi," in Seminar Nasional Teknik Kimia Kejuangan, 2016, p. 14. 